\title{
ЕФЕКТИВНІСТЬ ВИКОРИСТАННЯ ІНФОРМАЦІЙНИХ ТЕХНОЛОГІЙ ДЛЯ ПІДГОТОВКИ ФАХІВЦІВ ТА ОРГАНІЗАЦІЇ НАДАННЯ ПЕРВИННОЇ МЕДИКО-САНІТАРНОЇ ДОПОМОГИ СІЛЬСЬКОМУ НАСЕЛЕННЮ
}

\author{
ДВН3 “Тернопільський державний медичний університет імені І.Я. Горбачевського МОЗ України”
}

\begin{abstract}
Мета: з'ясувати ефективність використання інформаційних технологій для підготовки фрахівців та надання медичної допомоги на прикладі навчально-практичних центрів первинної медико-санітарної допомоги.

Матеріали і методи. Під час виконання роботи застосовувались методи теорії інформаційних систем та інформаційного моделювання, соціологічний та статистичний методи. 3 метою дослідження ефективності інформатизації закладу охорони здоров'я проведено аналіз амбулаторного прийому 2486 сільських мешканців.

Результати. Використання інформаційних та телемедичних технологій на первинному рівні дозволило покращити доступність та якість медичної допомоги, підвищити ефективність підготовки фахівців для майбутньої роботи у сільських амбулаторіях.

Висновки. Застосування інформаційних технологій та створення навчально-практичних центрів сприятиме покращенню лікувально-профрілактичної роботи у сільських населених пунктах.

КЛЮчОВІ СЛОВА: інформаційні технології, первинна медико-санітарна допомога, сільські заклади охорони здоров'я.
\end{abstract}

Застосування інформаційних технологій у медицині набуває все більшого значення. Ціла низка досліджень спрямована на вирішення проблем запровадження медичних інформаційних систем та технологій [1-5], які допомагають автоматизувати всі аспекти діяльності лікувальної установи. Надзвичайно важливим для підвищення якості надання медичних послуг є впровадження інформаційних технологій у роботу сільських лікувальних закладів. Проте не до кінця вирішеними залишаються проблеми інформаційного забезпечення для профрілактики та раннього діагностування захворювань, підтримки прийняття лікарських рішень, еорективного отримання лікарських консультацій та якісної підготовки орахівців [2].

Мета: з'ясувати ефективність використання інформаційних технологій для підготовки фрахівців та надання медичної допомоги на прикладі навчально-практичних центрів первинної медикосанітарної допомоги (НПЦПМСД).

Матеріали і методи. Для поліпшення якості медичного обслуговування сільського населення та підготовки висококваліфікованих фрахівців у п'яти сільських населених пунктах Тернопільської області створені НПЦПМСД. Усі заклади забезпечені доступом до мережі Інтернет, аудіо-, відеозв'язком. Кожний пункт обладнано базовими робочими станціями із мультимедійним персональним комп'ютером, принтером, а також комплектом спеціалізованих пристроїв: електрокардіографом
«Юкард-100» та мікроскопом із відеонасадкою. Для роботи із вищевказаним обладнанням наявне також стандартне, додаткове та спеціальне програмне забезпечення (драйвери принтерів та спеціалізованих пристроїв, морфометричні програми). Здійснюється передача алфавітно-цифрової, кольорової та динамічної візуально-графічної інформації. Програма «Реєстратура» передбачає введення анкетних даних усіх жителів села, де відмічаються діагностичні і лікувальні процедури, надані пацієнтам. 3 метою дослідження роботи закладу охорони здоров'я с. Зарубинці проведено аналіз амбулаторного прийому 2486 сільських мешканців. Під час виконання роботи застосовувались методи теорії інорормаційних систем та інформаційного моделювання, соціологічний та статистичний методи. Для обробки даних використані пакети програм MS Excel (Microsoft Office 2003).

Результати дослідження та їх обговорення. IHформатизація та автоматизація роботи НПЦПМСД здійснювалась шляхом використання сучасних інформаційних технологій, баз даних, створення інформаційної системи та автоматизації робочого місця працівника (рис. 1). Інфрормаційна система навчально-практичних центрів первинної медикосанітарної допомоги (ІСНПЦПМСД) об'єднана з інформаційними системами університетської лікарні (ІСУЛ) та кафедр клініко-лабораторної діагностики і патологічної анатомії із секційним курсом та судової медицини університету. 


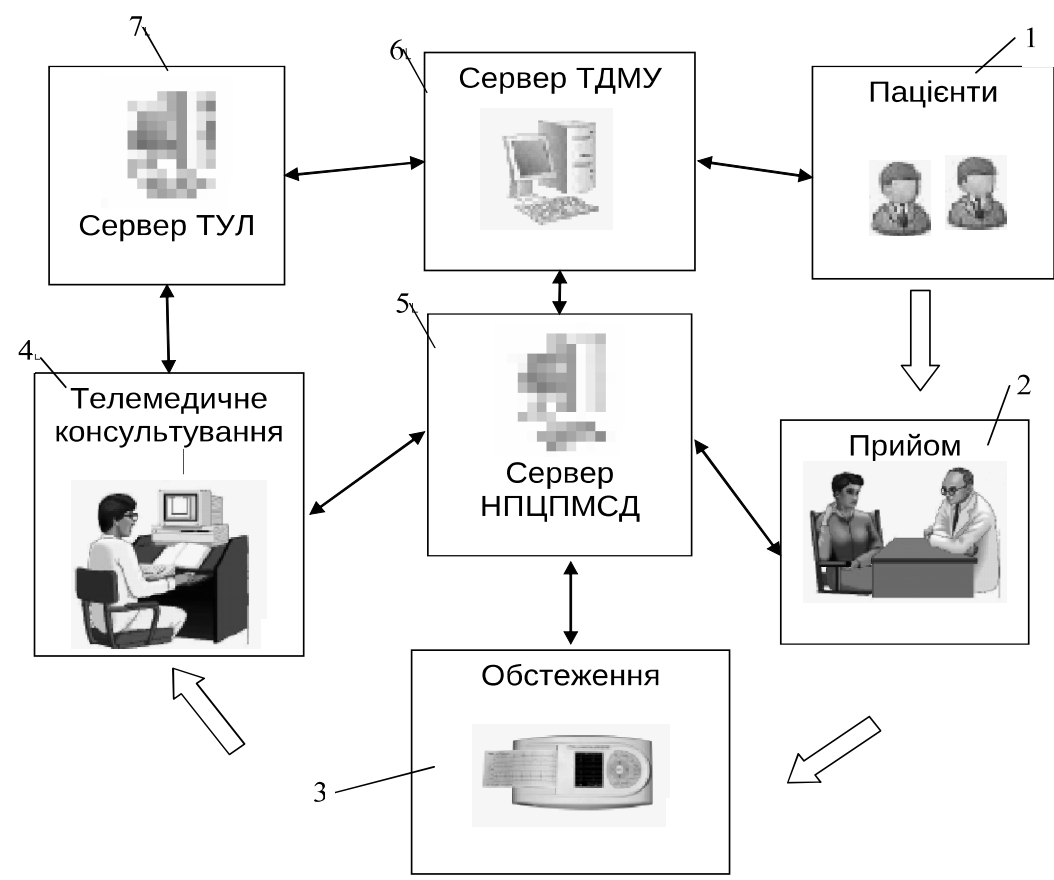

1 - пацієнти з можливістю самозапису на консультацію до фахівців університетської лікарні; 2 - амбулаторний прийом у НПЦПМСД; 3 - обстеження з фріксацією результатів у базі програми "Реєстратура"; 4 - телемедичне консультування лікарями університетської лікарні; 5 - сервер НПЦПМСД; 6 - сервер ТДМУ; 7 - сервер Тернопільської університетської лікарні (ТУЛ)

\section{Рuc.1. Концептуальне представлення інформаційної моделі системи НПцПМсД}

У нПцПМСД за допомогою телемедичного консультування $€$ можливість консультацій хворих провідними фрахівцями Тернопільської університетської лікарні в режимі on-line. 3 метою ранньої діагностики серцевої патології і визначення доцільності госпіталізації засобами GSM- та Інтернет-зв'язку електрокардіограми передаються у центр обробки та аналізу, який знаходиться на території університетської лікарні. Електронна база електрокардіограм допомагає у діагностиці серцевої патології при порівнянні результатів обстежень тих самих пацієнтів у різні періоди. Цитологічна експрес-діагностика забезпечується за допомогою мікроскопів із цисрровими відеокамерами та програмним аналізом зображення. За допомогою аудіо-, відеозв'язку та передачі зображень гінекологічних мазків здійснюється консультування спеціалістами касредр патологічної анатомії та клініко-лабораторної діагностики університету. Це дає можливість раннього виявлення не лише онкопатології, але й фонових та передракових процесів шийки матки.

Паралельно із впровадженням інфрормаційних технологій здійснювалась відповідна підготовка персоналу медичних пунктів, ФАПів та амбулаторії. Проводилося навчання працівників в якості користувачів для роботи зі спеціальними програмами та базами даних. Для майбутньої роботи в сільських лікувальних закладах здійснювалось таке навчання і для студентів-випускників та лікарів-інтернів за спеціальністю "Загальна практика - сімейна медицина". На базі НПЦПМСД для студентів забезпечена можливість засвоєння ряду практичних навичок, зокрема огляду хворих, ведення документації, роботи з медичною апаратурою, навичок у роботі із засобами віддаленого консультування. Одночасно з навчанням на базі НПЦПМСД проводилася лікувально-профілактична робота щодо надання первинної медичної допомоги населенню, раннього виявлення хворих, проведення диспансеризації та профрілактичних заходів. За період 2009-2012 рр. у НПЦПМСД було прийнято 5726 амбулаторних хворих. Проліковано вдома 1205 пацієнтів, на диспансерний облік взято 881 жителя вказаних сільських населених пунктів. Електрокардіографрію проведено 1892 пацієнтам.

Проведено аналіз низки показників роботи НПЦПМСД с. Зарубинці Збаразького району у період 32009 р. по 2012 р. Цей центр було створено першим. Також вивчалася діяльність ФАПу с. Зарубинці до створення НПЦПМСД (2007-2008рр.). За всі досліджувані роки виявлялась висока частка $(p<0,05)$ охоплення онкологічними профрілактичними оглядами (ОПО) і цитологічним обстеженням (ЦО) жіночого населення - від $(69,60 \pm 3,05) \%$ до $(100,00 \pm 0,00) \%$. Порівняльний аналіз виявив ріст кількості відвідувань ФАП на одного мешканця (рис. 2) з 2,2 відвідування у період 2007-2008 рр. до 2,8-3,0 відвідувань у період 2009-2012 рр. Кількість відвідувань вдома на одного мешканця знаходилась на рівні двох відвідувань у періоди 2007-2008 рр. та 2010-2011 рр. 




Рuc. 2. Порівняльний аналіз показників роботи НПЦПМСД (ФАП) с. Зарубинці Збаразького району Тернопільської області за 2007-2012 рр.

Лише у 2009 р., на початку роботи НПЦПМСД, зазначений показник був вищим і становив 2,3 відвідування на одного мешканця.

\section{Висновки}

Використання інформаційних та телемедичних технологій на первинному рівні дає можливість покращити якість медичної допомоги та підвищити ефективність підготовки висококваліфікованих фрахівців для майбутньої роботи у сільських амбулаторіях.
Зростання кількості відвідувань на одного мешканця у період роботи НПЦПМСД свідчить про добре сприйняття населенням закладів такого типу і вказує на те, що створення НПЦПМСД сприятиме покращенню лікувально-профрілактичної роботи у сільських населених пунктах.

Перспективиподальшихдослідженьпов'язані із запровадженням запропонованих інорормаційних інновацій у практику охорони здоров'я.

\section{Список літератури}

1. Ковальчук Л. Я. Обґрунтування використання інформаційних технологій для підготовки лікарів сімейної медицини та покращення якості медичної допомоги на первинному рівні / Л. Я. Ковальчук, В. П. Марценюк, П. Р. Сельський // Клин. инфоорматика и Телемедицина. - 2012. - Т. 8, Вып. 9. - С. 141-145.

2. Концепція інформатизації охорони здоров'я України / О. П. Мінцер, Ю. В. Вороненко, Л. Ю. Бабінцева [та ін.] // Медична інформатика та інженерія. - 2012. - № 3. - С. 5-29.

3. Медицинские инсрормационные системы: теория и практика / под ред. Г. И. Назаренко, Г. С. Осипова. - М. : ФИЗМАТЛИТ, 2005. - С. 320.

4. Мінцер О. П. Інформаційно-технологічні проблеми організації телемедичних консультатцій / О. П. Мінцер, В. В. Краснов, Г. Тахере // Мед. інфоорматика та інженерія. - 2011. - № 4. - С. 32-37.

5. Medical Informatics : Computer Applications in Health Care / Edward H. Shortliffe, Leslie E. Perreault, Gio Wiederhold, Lawrence M. Fagan. - Third edition. - Springer. - 2003. - 854 p.

\section{ЭФФЕКТИВНОСТЬ ИСПОЛЬЗОВАНИЯ ИНФОРМАЦИОННЫХ ТЕХНОЛОГИЙ ДЛЯ ПОДГОТОВКИ СПЕЦИАЛИСТОВ И ОРГАНИЗАЦИИ ПРЕДОСТАВЛЕНИЯ ПЕРВИЧНОЙ МЕДИКО-САНИТАРНОЙ ПО- МОЩИ СЕЛЬСКОМУ НАСЕЛЕНИЮ \\ П.Р. Сельський \\ ГВУЗ «Тернопольский государственный медицинский университет имени И. Я. Горбачевского МЗ Украины»}

Цель: выяснить эфффективность использования информационных технологий для подготовки специалистов и оказания медицинской помощи на примере учебно-практических центров первичной медико-санитарной помощи.

Материалы и методы. Во время выполнения работы применялись методы теории информационных систем и инорормационногомоделирования, социологическийистатистический методы. Сцелью исследования эфроективности инорорматизации учреждения здравоохранения проведен анализ амбулаторного приема 2486 сельских жителей.

Результаты. Использование иноормационных и телемедицинских технологий на первичном уровне позволило улучшить доступность и качество медицинской помощи, повысить эфреективность подготовки специалистов для будущей работы в сельських амбулаториях. 
Выводы. Использование инорормационных технологий и создание учебно-практических центров будет способствовать улучшению лечебно-профилактической работы в сельских населенных пунктах.

КЛЮЧЕВЫЕ СЛОВА: информационные технологии, первичная медико-санитарная помощь, сельские учреждения здравоохранения.

\section{EFFICIENCY OF INFORMATION TECHNOLOGIES FOR THE TRAINING OF MEDICAL SPECIALISTS AND ORGANIZATION OF THE PRIMARY HEALTH CARE AMONG RURAL POPULATION}

P.R. Selskyy

SHEI «Ternopil State Medical University by I. Ya. Horbachevsky Ministry of Health of Ukraine»

Objective: to find out efficiency of information technologies use for training and providing medical care on an example of educational and practical centres of the primary health care.

Materials and methods. During work performance methods of the theory of information systems and information modelling, sociological and statistical methods were applied. In order to study the effectiveness of information technologies implementation in health institution, we analyzed 2486 local patients during ambulatory visits.

Results. Use of information and telemedical technologies at primary level has allowed to improve the availability and quality of medical care, raise efficiency of specialists training for future work in rural ambulance stations.

Conclusions. Application of information technologies and creation of educational and practical centres will improve of health care in rural areas.

KEY WORDS: information technologies, primary health care, rural health care facilities.

\section{Відомості про автора:}

Рукопис надійшов у редакцію 20.06.2015

Сельський Петро Романович - д.мед.н., декан фракультету іноземних студентів, професор кафедри патологічної анатомії з секційним курсом та судової медицини ДВНЗ «Тернопільський державний медичний університет імені І.Я. Горбачевського МОЗ України»; тел.: 0352-25-39-98. 